\title{
Sharing Resources in Educational Communities
}

\author{
doi:10.3991/ijet.v5i2.857 \\ Allison Littlejohn and Anoush Margaryan \\ Glasgow Caledonian University, Glasgow, United Kingdom
}

\begin{abstract}
This study explores individuals' strategies for sharing and reusing educational resources within localised and distributed communities. Individual behaviours and preferences can determine the overall effectiveness of a community, therefore the study examined individuals' resource sharing strategies within either localised or distributed communities. Results suggest that individuals in both localised and distributed communities share educational resources and communicate with colleagues in surprisingly similar ways, though localised groups favour face-to-face communication. Overall, the distribution of the community seems to have surprisingly little impact on individuals' strategies for resource management. The survey results demonstrate that there are few major differences in the ways in which individuals within the localised and distributed communities share and collaborate around educational resources. The study concludes with scenarios for future sharing, based around two meta-trends arising from the literature: the trend towards open sharing in distributed communities.
\end{abstract}

Index Terms-learning communities; learning object repositories; mobility; knowledge sharing

\section{SHARING EDUCATIONAL RESOURCES}

\section{A. Benefits of sharing}

Every day individuals in thousands of educational communities around the world source, generate, integrate and share knowledge and resources. Although resource sharing in educational contexts is not a new phenomenon, technological and societal changes [4], means that the ways in which resources are shared is rapidly transforming in two main ways.

Firstly, the structure of communities is changing. Traditionally, educational materials were shared within localised groups. However, there is a trend towards resources being shared amongst groups of people who are not necessarily part of a single community. These changes mean that resource sharing is no longer limited to small, localised groups of people. Increasingly resources are being shared within dynamic and transient networked communities. Reference [3] defines a network as a 'fluid form of social entity in which members join, create and remove themselves from numerous informal learning and social connections'. At any point in time a network is likely to comprise a number of coherent, tightly bound clusters or groups. Nevertheless, within these structures the individual remains the primary unit of connectivity [15]. It is the actions of individuals that determines the coherence of a community. Community coherence, whether close-knit or loosely confederated, has been identified as one of a number of dimensions of communities affecting resource sharing [9]. According to [15] coherence has an impact on the personal skills, motivation and agility individuals require to source resources and maintain the right connections. Individual behaviours and preferences can determine the overall effectiveness of a community.

Other important dimensions of sharing communities are the purpose of the community; dialogue and means of communication within the community (online, face-toface, or mixed); roles and responsibilities of community members: the context within which the community exists (organizations, professional bodies, governments, etc.); the implicit and explicit rules that govern how the community functions (rules of conduct, rewards and incentives mechanisms, control of access and use of resources, etc.); and the teaching and learning approaches used within the community (for example, problem-based learning, collaborative learning) [9]. Consequently sharing within and across distributed communities has some fundamental differences to sharing within a localised community. Therefore people require different skills and technologies for interacting in localised and in distributed communities, choosing to interact through face-to-face discussions, e-mail, social networking systems, or combinations of these depending on who the individual interacts with and the nature of the interaction [12], [13] and [16]. Within online communities and networks individuals interact using a range of different tools that collectively form an ecology. Interactions supported by online tools complement face-to-face and phone exchanges, [7] and [5]. The ability to mix these different forms of interaction has not been designed into some resource sharing systems, limiting their uptake, since the processes of sharing on which these technologies are premised have been misaligned with users' preferred practice [2] and [8]. Therefore it is important to understand existing strategies for sharing and reusing educational resources within localised and distributed communities.

Secondly, resource exchange is shifting towards towards open sharing. A recent Horizon report highlights the growing number of resources available for sharing, from datasets, single or collaboratively-authored online texts, articles and notes to images, videos and sound files [10]. Increasingly these resources are being shared across open, dynamic environments utilising a variety of technology tools, rather than within closed, walled environments (ibid). The environment in which resources are shared can significantly influence the extent and nature of sharing within communities [9]. Important dimensions of these environments that affect sharing include:

1. The purpose of the technology tools or environment;

2. The grouping within which resources are being shared (for example the subject discipline);

3. The scope of sharing, for example at regional, national, or international level; 
4. The sector within which sharing is being supported by the tool. This includes schools, higher education and vocational institutions, hobby-based or workbased communities;

5. Key characteristics of users (teachers, students, publishers, institutions, employees or hobby enthusiasts), depending on the scope and sector;

6. The business model that governs the trading, and management of sharing, such as pay-per-view or open exchange.

A number of large scale initiatives have been working towards encouraging a culture of openly releasing and sharing education and knowledge resources. For example the MIT Open Courseware Initiative in the US (ocw.mit.edu), OpenLearn in the UK (openlearn.open.ac.uk) and the UK JISC Open Educational Resources programme (www.jisc.ac.uk/oer) collectively aim to encourage the open release and sharing of resources as an expected part of the educational resources creation cycle. National and international e-research and e-science programmes encourage open sharing and access to knowledge resources and research outputs in an openly accessible way that permits easy re-use. The central idea behind these initiatives is that open sharing can improve the efficiency and effectiveness of learning through economies of scale that enable learners and teachers to draw from diverse resources, enable dissemination and adoption of new approaches to learning and build collective knowledge [1], [6], [11] and [14]., These benefits of open sharing have not yet been realised, due to the limited degree of sharing within and across communities.

The aim of this paper is to explore the implications of different environments and structures for sharing. Firstly we explore individuals' existing strategies for sharing and reusing educational resources within localised and distributed communities. Secondly, we consider the impact of the trend towards open sharing of resources through consideration of scenarios of sharing. Thirdly, we propose a framework for future research into resource sharing within communities.

\section{Personal Resource Management Strategies WITHIN LOCALISED DISTRIBUTED COMMUNITIES}

To understand how strategies for sharing are likely to change when individuals share within different community structures, we must be aware of the various ways in which people share resources and collaborate within localised and distributed communities. This section outlines results of a survey of individuals' approaches to sharing within localised and distributed educational communities [8]. This study was part of a broader exploration of a range of issues in personal resource management strategies, including:

1. Strategies for storing and sharing "work-inprogress";

2. The types of files and educational resources stored and created;
3. Strategies for storing, sharing and delivering completed work;

4. Perceptions related to ownership of educational resources;

5. Strategies for discovering, reusing and repurposing resources.

\section{A. Data collection methodology}

Data was collected using an online questionnaire. The survey was open for one month in 2006. An invitation to complete the survey was e-mailed to a number of localised and distributed communities, including:

1. Faculty of Education and Social Work, University of Dundee, UK (localised community)

2. Department of Instrumentation, Faculty of Behavioural Sciences, University of Twente, The Netherlands (localised community)

3. Educational Technology Expertise Centre, Open University of the Netherlands (localised community)

4. Centre of Academic Practice and Learning Enhancement (CAPLE), University of Strathclyde, UK (localised community)

5. All Special Interest Groups (SIGs) within Centre for Educational Technology Interoperability and Standards, UK (distributed community)

6. Support Team, Joint Information Systems Committee (JISC) Digital Repositories Programme, UK (distributed community)

7. IEEE International Forum of Educational Technology and Society (distributed community).

In interpreting the survey results, it should be taken into consideration that, although the respondent group includes both localised and distributed communities, individual respondents are members of many different communities at the same time. To ensure that the findings were specifically related to the strategies within either localised or distributed communities, responses from individuals who had indicated membership in both localised and distributed communities were excluded from the final sample.

\section{B. Respondents}

The final sample of 197 respondents was categorised into two groups - localised and distributed communities. Individuals within localised communities are those who are most likely to share their resources with colleagues working in the same department or university. Distributed communities comprise those who choose to collaborate and share with peers in other organisations, nationally or internationally. Incomplete responses, as well as responses from individuals who share with both localised and distributed communities at the same time, were excluded from the analysis. The majority of respondents belonged to the localised community category $(88 \%, n=157)$. Table 1 provides a summary of the respondents' background information, including country of origin, discipline and role. 
TABLE I

PARTICIPANTS' BACKGROUND DATA

\begin{tabular}{|c|c|c|c|}
\hline & & $\begin{array}{c}\text { Localised } \\
\text { communities } \\
\mathbf{N}=157\end{array}$ & $\begin{array}{c}\text { Distributed } \\
\text { communities } \\
\mathrm{N}=22\end{array}$ \\
\hline \multirow{7}{*}{$\begin{array}{l}\text { Country } \\
\text { of origin }\end{array}$} & England & $96(61.1 \%)$ & $17(77.3 \%)$ \\
\hline & Scotland & $25(15.9 \%)$ & $2(9.1 \%)$ \\
\hline & Wales & $7(5.4 \%)$ & $0(0.0 \%)$ \\
\hline & Other European Union & $11(7.0 \%)$ & $0(0.0 \%)$ \\
\hline & USA or Canada & $7(4.5 \%)$ & $0(0.0 \%)$ \\
\hline & Australasia & $6(3.8 \%)$ & $3(13.6 \%)$ \\
\hline & Other & $5(3.2 \%)$ & $0(0.0 \%)$ \\
\hline \multirow[t]{8}{*}{ Discipline } & $\begin{array}{l}\text { Arts, languages and } \\
\text { history }\end{array}$ & $21(13.4 \%)$ & $4(18.2 \%)$ \\
\hline & $\begin{array}{l}\text { Mathematics, comput- } \\
\text { ing and engineering }\end{array}$ & $23(14.6 \%)$ & $1(4.5 \%)$ \\
\hline & $\begin{array}{l}\text { Sciences and environ- } \\
\text { mental sciences }\end{array}$ & $7(4.5 \%)$ & $1(4.5 \%)$ \\
\hline & Health and medicine & $8(5.1 \%)$ & $2(9.1 \%)$ \\
\hline & Social sciences & $12(7.6 \%)$ & $2(9.1 \%)$ \\
\hline & Education & $48(30.6 \%)$ & $4(18.2 \%)$ \\
\hline & $\begin{array}{l}\text { Business and manage- } \\
\text { ment }\end{array}$ & $9(5.7 \%)$ & $0(0.0 \%)$ \\
\hline & Other & $29(18.5 \%)$ & $8(36.4 \%)$ \\
\hline \multirow[t]{9}{*}{ Role } & Teaching & $16(10.2 \%)$ & $1(4.5 \%)$ \\
\hline & Research & $6(3.8 \%)$ & $1(4.5 \%)$ \\
\hline & Teaching and research & $20(12.7 \%)$ & $2(9.1 \%)$ \\
\hline & $\begin{array}{l}\text { Learning technology } \\
\text { support }\end{array}$ & $22(14.0 \%)$ & $1(4.5 \%)$ \\
\hline & $\begin{array}{l}\text { Educational develop- } \\
\text { ment support }\end{array}$ & $2(1.3 \%)$ & $2(9.1 \%)$ \\
\hline & Staff development & $4(2.5 \%)$ & $0(0.0 \%)$ \\
\hline & Library staff & $26(16.6 \%)$ & $1(4.5 \%)$ \\
\hline & Other & $5(3.2 \%)$ & $2(9.1 \%)$ \\
\hline & $\begin{array}{l}\text { Across various areas } \\
\text { (ranging from } 2 \text { to } 7 \\
\text { roles) }\end{array}$ & 55 (35.0\%) & $11(50 \%)$ \\
\hline
\end{tabular}

\section{RESULTS}

In this section we outline the responses to survey questions on strategies for personal resource management. Some options receiving no responses were removed, but are available within the full study (Margaryan, 2006).

Question 1. When you are developing an educational resource, do you ever share your 'work-in-progress' for comment/collaboration? If so who do you share your 'work-in-progress' with?

All respondents in the localised and distributed communities indicated that they shared their work-in-progress' with others. Within the localised community group, the majority of respondents chose to share their work with departmental colleagues, whilst in the distributed community most indicated several responses comprising contacts in other UK educational and non-educational, as well as in overseas institutions. Table 2 provides a summary of responses.
TABLE II.

FREQUENCY (IN \%) OF RESPONDENTS SHARING THEIR WORKING DOCUMENTS WITH OTHERS

\begin{tabular}{|l|c|c|}
\hline & $\begin{array}{c}\text { Localised } \\
\text { communities } \\
\mathbf{N}=\mathbf{1 5 7}\end{array}$ & $\begin{array}{c}\text { Distributed } \\
\text { communities } \\
\mathbf{N}=\mathbf{2 2}\end{array}$ \\
\hline Departmental colleagues & $84(53.5 \%)$ & $0(0.0 \%)$ \\
\hline Colleagues in the wider university & $10(6.4 \%)$ & $0(0.0 \%)$ \\
\hline $\begin{array}{l}\text { Contacts in other UK educational } \\
\text { organisations }\end{array}$ & $0(0.0 \%)$ & $1(4.5 \%)$ \\
\hline $\begin{array}{l}\text { Contacts in educational organisa- } \\
\text { tions overseas }\end{array}$ & $0(0.0 \%)$ & $2(9.1 \%)$ \\
\hline $\begin{array}{l}\text { Colleagues and contacts in various } \\
\text { areas (more than one response) }\end{array}$ & $63(40.1 \%)$ & $19(86.4 \%)$ \\
\hline
\end{tabular}

Question 2. What methods do you use to share your work-in-progress?

Table 3 summarises the methods respondents use to share their work-in-progress. The majority of respondents in both community groups indicated they had adopted multiple strategies for sharing, but no respondents in either group indicated use of conventional post per se to share their work-in-progress. As expected, no-one in the distributed communities group shared resources 'by hand' (i.e. internal mail)

TABLE III.

FREQUENCY (IN \%) OF PARTICIPANTS' METHODS USED TO SHARE WORKIN-PROGRESS

\begin{tabular}{|l|c|c|}
\hline & $\begin{array}{c}\text { Localised } \\
\text { communities } \\
\mathbf{N}=\mathbf{1 5 6}\end{array}$ & $\begin{array}{c}\text { Distributed } \\
\text { communities } \\
\mathbf{N}=\mathbf{2 2}\end{array}$ \\
\hline Conventional post & $0(0.0 \%)$ & $0(0.0 \%)$ \\
\hline Email & $28(17.9 \%)$ & $6(27.3 \%)$ \\
\hline Personal website & $5(3.2 \%)$ & $1(4.5 \%)$ \\
\hline By hand & $1(0.6 \%)$ & $0(0.0 \%)$ \\
\hline Other & $10(6.4 \%)$ & $1(4.5 \%)$ \\
\hline $\begin{array}{l}\text { Across various methods (several } \\
\text { responses) }\end{array}$ & $112(71.8 \%)$ & $14(63.6 \%)$ \\
\hline
\end{tabular}

Responses can be grouped into three broad categories: a) use of technology encompassing email, personal website, and other online tools, b) use of conventional methods, such as by post, by hand, and other methods such as phoning or face-to-face meetings, and c) a range of methods used equally across a) and b). Table 4 indicates that the majority of respondents in the localised communities predominantly use some sort of technological method rather than conventional techniques. Respondents in the distributed communities only used technological tools. This dominant use of technology was statistically significant $\left[\chi^{2}=131.88, \mathrm{df}=2, \mathrm{p}=.000\right]$.

TABLE IV

FREQUENCY (IN \%) OF PARTICIPANTS' PREDOMINANTLY USED METHODS TO SHARE WORK-IN-PROGRESS

\begin{tabular}{|l|c|c|}
\hline & $\begin{array}{c}\text { Localised } \\
\text { communities } \\
\mathbf{N}=\mathbf{1 5 6}\end{array}$ & $\begin{array}{c}\text { Distributed } \\
\text { communities } \\
\mathbf{N = 2 2}\end{array}$ \\
\hline Use of technology & $107(68.6 \%)$ & $22(100 \%)$ \\
\hline Use of conventional methods & $8(5.1 \%)$ & $0(0.0 \%)$ \\
\hline $\begin{array}{l}\text { Combination of technology and } \\
\text { conventional methods }\end{array}$ & $41(26.3 \%)$ & $0(0.0 \%)$ \\
\hline
\end{tabular}


Question 3. How do your colleagues comment or collaborate on the work?

The majority of respondents in both groups indicated that they had used multiple methods to allow colleagues to comment on their work (Table 5).

TABLE V.

FREQUENCY (IN \%) OF PARTICIPANTS' COLLABORATION METHODS ON THEIR WORK-IN-PROGRESS

\begin{tabular}{|l|c|c|}
\hline & $\begin{array}{c}\text { Localised com- } \\
\text { munities } \\
\mathbf{N}=\mathbf{1 5 5}\end{array}$ & $\begin{array}{c}\text { Distributed } \\
\text { communities } \\
\mathbf{N = 2 1}\end{array}$ \\
\hline In a face-to-face meeting & $20(12.9 \%)$ & $4(19 \%)$ \\
\hline In a separate document & $2(1.3 \%)$ & $0(0.0 \%)$ \\
\hline $\begin{array}{l}\text { In the same document by inserting } \\
\text { text }\end{array}$ & $4(2.6 \%)$ & $1(4.8 \%)$ \\
\hline $\begin{array}{l}\text { In the same document using some } \\
\text { sort of automated collaboration } \\
\text { feature }\end{array}$ & $3(1.9 \%)$ & $2(9.5 \%)$ \\
\hline Other (several re- & $6(3.9 \%)$ & $14(66.7 \%)$ \\
\hline $\begin{array}{l}\text { Various methods } \\
\text { sponses) }\end{array}$ & $120(77.4 \%)$ & $21(95.5 \%)$ \\
\hline
\end{tabular}

Question 4. Do you share your completed educational resources with others?

The majority of individuals in both the localised communities group $(\mathrm{n}=144(91.7 \%))$ and the distributed communities group $(n=21(95.5 \%))$ reported that they share resources with others.

Question 5. In the last year, what proportion of the educational resources you have developed was created from scratch?

The majority of respondents in the localised communities reported that more than half of their educational resources were created from scratch. The majority within the distributed communities group indicated less than half of their resources were newly created.

TABLE VI.

FREQUENCY (IN \%) OF MATERIALS CREATED FROM SCRATCH

\begin{tabular}{|l|c|c|}
\hline & $\begin{array}{c}\text { Localised } \\
\text { communities } \\
\mathbf{N}=\mathbf{1 5 7}\end{array}$ & $\begin{array}{c}\text { Distributed } \\
\text { communities } \\
\mathbf{N}=\mathbf{2 2}\end{array}$ \\
\hline None & $6(3.8 \%)$ & $4(18.2 \%)$ \\
\hline Less than half & $62(39.5 \%)$ & $10(45.5 \%)$ \\
\hline More than half & $82(52.5 \%)$ & $6(27.3 \%)$ \\
\hline $100 \%$ & $7(4.5 \%)$ & $2(9.1 \%)$ \\
\hline
\end{tabular}

Question 6. In the last year, what proportion of the educational resources you have developed has been repurposed from your own existing materials (i.e. you have changed or edited your own materials)?

The majority of respondents in the localised communities group reported that less than half of their educational resources were based on existing materials. Within the distributed communities group, the majority indicated that more than half of their resources had been repurposed.
TABLE VII.

FREQUENCY (IN \%) OF MATERIALS REPURPOSED FROM INDIVIDUALS' OWN EXISTING RESOURCES

\begin{tabular}{|l|c|c|}
\hline & $\begin{array}{c}\text { Localised } \\
\text { communities } \\
\mathbf{N}=\mathbf{1 5 7}\end{array}$ & $\begin{array}{c}\text { Distributed } \\
\text { communities } \\
\mathbf{N}=\mathbf{2 2}\end{array}$ \\
\hline None & $8(5.1 \%)$ & $2(9.1 \%)$ \\
\hline Less than half & $76(48.4 \%)$ & $9(40.9 \%)$ \\
\hline More than half & $71(45.2 \%)$ & $11(50.0 \%)$ \\
\hline $100 \%$ & $2(1.3 \%)$ & $0(0.0 \%)$ \\
\hline
\end{tabular}

Question 7. In the last year, what proportion of the educational resources you have developed have been repurposed from material created by others (i.e. you have changed or edited others' materials)?

The majority of respondents in both groups reported that less than half of the educational resources they developed had been repurposed from materials sourced from others.

TABLE VIII.

FREQUENCY (IN \%) OF MATERIALS REPURPOSED FROM RESOURCES CREATED BY OTHERS

\begin{tabular}{|l|c|c|}
\hline & $\begin{array}{c}\text { Localised } \\
\text { communities } \\
\mathbf{N}=\mathbf{1 5 7}\end{array}$ & $\begin{array}{c}\text { Distributed } \\
\text { communities } \\
\mathbf{N}=\mathbf{2 2}\end{array}$ \\
\hline None & $29(18.5 \%)$ & $3(13.6 \%)$ \\
\hline Less than half & $110(70.1 \%)$ & $15(68.2 \%)$ \\
\hline More than half & $17(10.8 \%)$ & $2(9.1 \%)$ \\
\hline $100 \%$ & $1(0.6 \%)$ & $2(9.1 \%)$ \\
\hline
\end{tabular}

Question 8. In the last year, what proportion of the educational resources you have delivered have been materials created by others, reused by you as is?

The majority of respondents in localised and distributed communities groups reported that none of the resources they used in teaching were based on materials created by others. However, responses range from 'none' to 'less than half'.

TABLE IX

FREQUENCY (IN \%) OF MATERIALS REUSED AS IS FROM RESOURCES CREATED BY OTHERS

\begin{tabular}{|l|c|c|}
\hline & $\begin{array}{c}\text { Localised com- } \\
\text { munities } \\
\mathbf{N = 1 5 7}\end{array}$ & $\begin{array}{c}\text { Distributed } \\
\text { communities } \\
\mathbf{N}=\mathbf{2 2}\end{array}$ \\
\hline None & $79(50.3 \%)$ & $11(50.0 \%)$ \\
\hline Less than half & $66(42.0 \%)$ & $10(45.5 \%)$ \\
\hline More than half & $12(7.6 \%)$ & $1(4.5 \%)$ \\
\hline $100 \%$ & $0(0.0 \%)$ & $0(0.0 \%)$ \\
\hline
\end{tabular}

Question 9. In the last year, what proportion of the educational resources you have delivered have been materials previously created by you, reused as is?

The majority of individuals in both groups indicated that less than half of the educational resources they used in teaching were based on their own existing materials. 
TABLE X.

FREQUENCY (IN \%) OF MATERIALS REUSED AS IS FROM OWN RESOURCES

\begin{tabular}{|l|c|c|}
\hline & $\begin{array}{c}\text { Localised com- } \\
\text { munities } \\
\mathbf{N}=\mathbf{1 5 7}\end{array}$ & $\begin{array}{c}\text { Distributed } \\
\text { communities } \\
\mathbf{N}=\mathbf{2 2}\end{array}$ \\
\hline None & $35(22.3 \%)$ & $4(18.2 \%)$ \\
\hline Less than half & $81(51.6 \%)$ & $11(50.0 \%)$ \\
\hline More than half & $38(24.2 \%)$ & $7(31.8 \%)$ \\
\hline $100 \%$ & $3(1.9 \%)$ & $0(0.0 \%)$ \\
\hline
\end{tabular}

\section{DISCUSSION}

The results suggest that individuals interact with distributed colleagues in largely ways similar to how they work together with localised collaborators, though localised groups favour face-to-face communication. Overall, distribution of communities seems to have surprisingly little impact on individuals' existing behaviours and strategies for resource management. The survey results demonstrate that there are few major differences in the ways in which individuals within localised and distributed communities currently share and collaborate around educational resources.

The groups surveyed in this study represent opposite ends of a community spectrum, since they represent either localised or distributed communities. In reality, community involvement is dynamic, therefore individuals are likely to participate within both localised and distributed communities $(13.9 \%$ of respondents were active within both types of communities). Although there are number factors likely to influence the outcome, this study provides valuable observations regarding the ways individuals share, source, and collaborate around resources. These factors can be grouped around the important dimensions of technology tools outlined in the introduction [9]: purpose, users, sector and scope, grouping and business model.

The purpose of sharing is often similar for individuals, wither within a localised or distributed community, though grouping may have some influence (ie if resources are grouped and shared around a single discipline they may be shared differently than if they were shared within a broader context). Individuals in both groups share workin-progress resources with others, so environments for sharing resources should include tools for sourcing, sharing and collaborating around work-in-progress materials.

All resources were used within a single sector (the Education). However, the scope of sharing (ie whether local, national, or international) is likely to be different depending on the community type. Over half the individuals within localised communities share with colleagues within the same department, while distributed groups tend to share across a broader range of communities. However, the scope of sourcing is largely the same with large numbers of individuals within both types of communities sourcing and gathering educational resources from a variety of locations. This result has implications for open sharing since it demonstrates that, while individuals operating within distributed communities may be motivated to search for resources widely, they may not wish to share their own resources openly.

The predominant business model within both localised and distributed appears to be one of limited, but cost free exchange - in other words 'share and share alike'. This could be because both groups rely heavily on technology to share work in progress documents, rather than completed resources. Although both groups use similar methods to share resources, distributed communities favour email slightly more than localised communities do.

Methods of collaboration of users during development of these resources are notably varied for each type of community. More individuals within distributed communities collaborate on work-in-progress documents in a face-toface mode than those in localised groups. This result may be due to the margin of error within distributed communities, so the level of reliance on face-to-face collaboration might be about the same for both localised and distributed communities.

In this study we focused on the influence of the structure of the community - whether localised or distributed. However, another important factor that will influence sharing is whether the sharing is open or closed. Combining these two variables we can formulate four distinct scenarios of sharing and reuse of resources within communities.

\section{SCENARIOS AND FUTURE STRATEGIES}

In this section we outline four scenarios that could form a basis for future research into resource sharing in localised and distributed communities. These scenarios are structured around two variables identified earlier as important for resource sharing - community structure and sharing strategy (Figure 1). Community structure relates to an individual's transition from working in a localised situation to working in a distributed context. Sharing strategy incorporates the transition from closed to open sharing. These factors can vary independently.

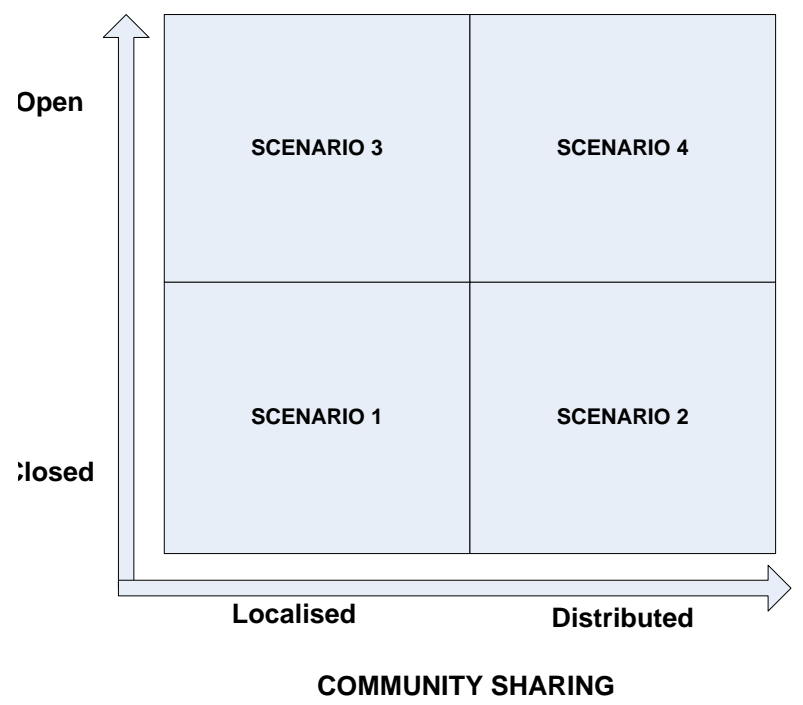

Figure 1. Scenarious of sharing

In order to understand the implications of community structure and sharing strategy for resource sharing it is important to consider the transition from one scenario to another. These transitions and implications are outlined in Table 11 
TABLE XI.

SCENARIOS (S) OF SHARING AND IMPLICATIONS FOR SHARING

\begin{tabular}{|c|c|c|}
\hline $\begin{array}{l}\text { Scenario/ Tran- } \\
\text { sition }\end{array}$ & Description & $\begin{array}{l}\text { Implications for shar- } \\
\text { ing and collaboration }\end{array}$ \\
\hline $\begin{array}{l}\text { From S1 closed } \\
\text { sharing within } \\
\text { localised com- } \\
\text { munity to } \\
\text { S2 closed sharing } \\
\text { within distributed } \\
\text { community }\end{array}$ & $\begin{array}{l}\text { In this transition, the } \\
\text { individual moves from } \\
\text { sharing resources within } \\
\text { a localised group com- } \\
\text { munity to sharing } \\
\text { within a distributed } \\
\text { community. }\end{array}$ & $\begin{array}{l}\text { While working within a } \\
\text { distributed community } \\
\text { the individual is likely } \\
\text { to seek for resources } \\
\text { from a variety of } \\
\text { sources, however strate- } \\
\text { gies for sharing are } \\
\text { likely to stay the same. } \\
\text { In order to maximise the } \\
\text { potential for sharing, the } \\
\text { individual should seek } \\
\text { ways of sharing openly } \\
\text { with others (ie move } \\
\text { towards S4) }\end{array}$ \\
\hline $\begin{array}{l}\text { From S1 closed } \\
\text { sharing within } \\
\text { localised com- } \\
\text { munity to S3 } \\
\text { open sharing } \\
\text { within localised } \\
\text { community to }\end{array}$ & $\begin{array}{l}\text { In this scenario an indi- } \\
\text { vidual moves to open } \\
\text { sharing while operating } \\
\text { with his or her existing, } \\
\text { localised community. } \\
\text { He or she will continue } \\
\text { sharing resources with a } \\
\text { localised community of } \\
\text { colleagues, but will } \\
\text { make these resources } \\
\text { available to the wider } \\
\text { community. }\end{array}$ & $\begin{array}{l}\text { The individual will seek } \\
\text { appropriate tools for } \\
\text { open sharing and will } \\
\text { have to consider legal } \\
\text { issues (for example, } \\
\text { have any aspects of the } \\
\text { resource been copied } \\
\text { from elsewhere?). }\end{array}$ \\
\hline $\begin{array}{l}\text { From S1 closed } \\
\text { sharing within } \\
\text { localised com- } \\
\text { munity to } \\
\text { S4 open sharing } \\
\text { within distributed } \\
\text { community }\end{array}$ & $\begin{array}{l}\text { In this case, an individ- } \\
\text { ual moves to a distrib- } \\
\text { uted community and } \\
\text { shares resources openly. }\end{array}$ & $\begin{array}{l}\text { Processes of sharing } \\
\text { should be adapted to } \\
\text { those of the new com- } \\
\text { munity, and the types of } \\
\text { resources may change } \\
\text { significantly. }\end{array}$ \\
\hline
\end{tabular}

In conclusion, this study indicates that individuals in localised and distributed communities share educational resources in similar ways. However, the focus of this investigation was around resource sharing strategies within either localised or distributed communities. The study did not investigate transitions between these communities, nor did it examine the effects of change of role and location in detail. Further studies are required to ascertain the implications of such transitions upon individuals' strategies and tools for sharing.

\section{ACKNOWLEDGMENTS}

The authors would like to thank the UK Joint Information Systems Committee for funding the CDLOR (Community Dimensions of Learning Object Repositories) project of which this study forms a part. We would also like to thank our colleagues Dr. Colin Milligan, Sarah Currier, Professor David Nicol (from the CDLOR project team) and Gabrielle Vojt for assistance with data analysis.

\section{REFERENCES}

[1] Campbell, L. (2003). Engaging with the learning object economy In A. Littlejohn (Ed.), Reusing online resources: A sustainable approach to e-learning (pp. 35-45). London: Kogan Page.

[2] Dobson, M., LeBlanc, D., \& Burgoyne, D. (2004). Transforming tensions in learning technology design: Operationalising Activity Theory. Canadian Journal of Learning and Technology, 30(1). Retrieved August 18, 2007 from http://www.cjlt.ca/vol30.1/cjlt301 art2.html
[3] Dron, J. \& Anderson, T. (2007). Collectives, networks and groups in social software for e-learning. In T. Bastiaens \& S. Carliner (Eds.), Proceedings of World Conference on E-Learning in Corporate, Government, Healthcare, and Higher Education 2007 (pp. 2460-2467). Chesapeake, VA: AACE.

[4] Hardt, M. \& Negri, A. (2008). Multitude. London: Penguin

[5] Haythornthwaite, C. (1998), A Social Network Study of the Growth of Community among Distance Learners. Information Research 4. Retrieved February 12, 2010, from, http://informtionr.net/ir/4-1/paper49.html

[6] Koper, R., Pannekeet, K., Hendriks, M., \& Hummel, H. (2004). Building communities for the exchange of learning objects: Theoretical foundations and requirements. ALT-J Research in Learning Technology, 12(1), 21-35.

[7] Larsen, J., Urry, J. \& Axhausen, K.W. (2006), Social Networks and Future Mobilities, Report to the Horizons Programme of the Department for Transport. Department of Sociology, University of Lancaster and IVT, ETH Zürich, Lancaster and Zürich. doi:10.1142/S1793206806000184

[8] Margaryan, A. (2006). Report on personal resource management strategies survey. CD-LOR Deliverable 7. JISC, UK. Retrieved August 18, 2007 from http://academy.gcal.ac.uk/cdlor/CDLORdeliverable7 PRMSreport.pdf

[9] Margaryan, A., Currier, S., Littlejohn, A., \& Nicol, D. (2006). Learning communities and repositories. CDLOR project desk research report. JISC, UK. Retrieved August 18, 2007, from http://academy.gcal.ac.uk/cd-lor/learningcommunitiesreport.pdf

[10] New Media Consortium (2009). Horizon report. Retrieved February 12,2010 , from http://www.nmc.org/publications/2009horizon-report

[11] Oliver, R. (2005). Using a blended learning approach to support problem-based learning with first year students in large undergraduate classes. In C. Looi, D. Joassen \& M. Ikeda,(Eds). Towards Sustainable and Scalable Educational Innovations Informed by the Learning Sciences. (pp. 848-851). Amsterdam: IOS Press.

[12] Schnorf, S. (2005), Like Text to Likes: Diffusion networks in Mobile Communication. Workshop: Frontiers in Transportation: Social and Spatial Interactions. Amsterdam, Netherlands, 2-6 July.

[13] Senbil, M. \& Kitamura, R. (2003), Simultaneous Relationships between Telecommunications and Activities. 10th International Conference on Travel Behaviour Research. Lucerne, 10-15 August.

[14] Sharpe, R., Beetham, H. \& Ravenscroft, A. (2004). Active Artifacts: Representing our Knowledge of Learning and Teaching, Educational Developments, 5n (2), 16-21

[15] Wellman, B, Hogan, B, Berg, B, Boase, J, Carrasco, J, Côté, R, Kayahara, T, Kennedy, T.L.M., \& Tran, T. (2006) Connected Lives: The Project, Chapter 8, Networked Neighbourhoods(Ed Purcell, P) London: Springer, 2006

[16] Ziovas, S. \& Grigoriadou, M. (2007). Boundary crossing and knowledge sharing in a web-based community. Paper presented at the International Association for Development of the Information Society (IADIS) Conference on Web-based Communities, Salamanca,Spain $\quad$ http://www.iadis.org/confman_wbc2007/ accepted.asp\#

[17] Littlejohn, A., \& Margaryan, A. (2006). Cultural issues in the sharing and reuse of resources for learning. Research and Practice in Technology-Enhanced Learning, 1(3), 269-284.

\section{AUTHORS}

Prof Allison Littlejohn is a Chair of Learning Technology and Director of the Caledonian Academy at Glasgow Caledonian University.

Dr. Anoush Margaryan is a Lecturer in Learning Technology in the Caledonian Academy at Glasgow Caledonian University.

Manuscript received February $24^{\text {th }} 2009$. Published as resubmitted by the authors May $24^{\text {th }} 2010$. 